\title{
Crowd-based innovaties: verschuivende verantwoordelijkheden in een institutional void
} Thijs Slot, Eefje Cuppen, Neelke Doorn, Maria Galeano Galvan \& Bram Klievink

Note: This is the author's version of the accepted manuscript. The full and final paper was published in 'Bestuurskunde' 26 (3), 2017.

Please cite this paper as: Slot, T., Cuppen, E., Doorn, N., Galeano Galvan, M., \& Klievink, B. (2017). Crowd-based innovaties: verschuivende verantwoordelijkheden in een institutional void. Bestuurskunde, 26(3), 31-42.

\begin{abstract}
De crowd speelt steeds vaker een sleutelrol in innovaties. Dergelijke 'crowd-based innovaties' bieden veel kansen voor vernieuwing in socio-technische systemen, bijvoorbeeld doordat meer mensen, makkelijker mee kunnen doen. Tegelijkertijd brengen zij belangrijke uitdagingen met zich mee doordat deze nieuwe praktijken plaatsvinden in een gevestigde institutionele en governance context. Deze dynamiek is te vangen in het idee van een 'institutional void': de spanning tussen (radicaal) nieuwe initiatieven en de geijkte structuren, regels en routines. Dit roept vragen op over het waarborgen van (publieke) waarden bij crowd-based innovaties. In dit artikel betogen we dat dit fenomeen vraagt om meer, gedegen empirisch onderzoek maar dat ook normatieve kwesties moeten worden meegenomen. Aan de hand van een typologie en drie voorbeelden wordt deze dynamiek beschreven en komen we tot een multidisciplinaire onderzoeksagenda voor andere governance structuren, waarbij innovaties niet voor de voet gelopen worden maar er wel aandacht blijft voor de waarde van bestaande instituties.
\end{abstract}

Keywords: responsible innovation, institutional void, crowd-based innovations, governance

\section{English summary:}

\section{Crowd-based innovations: shifting responsibilities in an institutional void}

The crowd increasingly plays a key role in facilitating innovations in a variety of sectors, spurred on by IT-developments and the concomitant increase in connectivity. Initiatives in this direction, captured under the umbrella-term 'crowd-based innovations', offer novel opportunities in socio-technical systems by increasing the access, reach and speed of services. At the same time, they signify important challenges because these innovations occur in a context of traditional, well-established institutional and governance structures and practices. This dynamic is captured in the idea of the 'institutional void': the tension between traditional structures and (radically) new initiatives. Existing rules, standards and practices are challenged, which raises questions about the safeguarding of public values such as quality, legitimacy, efficiency and governance of crowd-based innovations. This article argues that understanding these tensions requires supplementing empirical research with an explicitly normative dimension to reach thorough and balanced conclusions to facilitate innovation while protecting the valuable elements in existing rules and regulations. Illustrated by a number of short examples, we propose a multidisciplinary research agenda towards formulating appropriate governance structures. 


\section{Inleiding}

We zien steeds meer innovaties waarbij burgers taken en verantwoordelijkheden op zich nemen die voorheen waren voorbehouden aan overheden en bedrijven. Digitale communicatietechnieken stellen (grote) groepen mensen in staat zich te mobiliseren en betrokken te raken bij tal van vraagstukken en diensten die voorheen aan grote instellingen, bedrijven en overheden waren voorbehouden. Denk hierbij bijvoorbeeld aan de sharing economy, waar digitale platformen om eigendommen en diensten uit te wisselen tot grote populariteit uitgroeien. Andere bekende voorbeelden van crowd-based innovaties zijn te vinden rondom kennis en informatie (crowdsourcing en citizen science) en financiering (crowdfunding). De crowd lijkt dus aan zet. Met crowdfunding werd in 2016170 miljoen opgehaald $^{1}-$ $33 \%$ meer dan het jaar daarvoor, de MAEX telt inmiddels 1150 maatschappelijke initiatieven ${ }^{2}$, er zijn 83 makerspaces in Nederland ${ }^{3}$ en via Airbnb werden vorig jaar 1,7 miljoen overnachtingen geboekt, alleen al in Amsterdam ${ }^{4}$. De traditionele rollen van bedrijven, investeerders, onderzoekersgroepen en overheden worden in dit soort crowd-based innovaties (CBI's) overgenomen door een veelheid aan kleine partijen, met vaak een compleet andere werkwijze.

CBI's zijn sociale innovaties, die mede mogelijk worden gemaakt door technische innovaties op het gebied van ICT (vergemakkelijkt mobilisatie en coördinatie), productietechnieken (denk aan 3D printen) en andere ontwikkelingen (zoals die rondom betaalbare kleinschalige energieopwekking). Deze stellen groepen mensen steeds meer in staat om min of meer bottom-up tot innovatie te komen. De reikwijdte van toepassingen is breed: in de context van smart cities zijn er lokale gemeenschappen die zelf met de publieke ruimte aan de slag gaan, lokale energie communities maken gebruik van technische innovaties in energieopwekking om meer grip te krijgen op energieopwekking en gebruik, en digital humanitarians proberen de ontzagwekkende hoeveelheid data die mogelijk relevant is in een crisissituatie op een nuttige wijze in te zetten om iets voor de oplossing van die crisis te betekenen.

Of het nu gaat om nieuwe bedrijfsactiviteiten waarin grenzen tussen aanbieders en klanten vervagen, of om activiteiten met een sociaal of maatschappelijk doel, de verschillende varianten van CBI delen in ieder geval dat actoren die voorheen geen of slechts een passieve rol speelden, nu actief deelnemen en nieuwe rollen vervullen, dan wel traditionele rollen overnemen. CBI heeft de potentie om bij te dragen aan inclusieve en responsieve innovaties. Tegelijkertijd bestaat de kans dat verschillen tussen verschillende maatschappelijke of socio-economische groepen groeien, doordat niet iedereen op een gelijke manier kan deelnemen. CBI impliceert een transitie van waar en bij wie verantwoordelijkheden liggen: van individuen naar de crowd, van overheid naar burgers, van mensen naar algoritmes. Vanwege deze verschuiving van verantwoordelijkheden van partijen met een democratisch legitieme basis om te handelen naar partijen die deze basis ontberen, kan CBI een uitdaging zijn voor democratische waarden zoals representativiteit, verantwoording en legitimiteit. Deze uitdaging wordt des te urgenter gezien de toenemende decentralisatie en de overdracht van verantwoordelijkheden van de centrale overheid naar meer lokale instanties (zoals lagere overheden maar ook naar burgers). Wat dat betreft spelen CBI's zich af in wat Hajer (2003) een 'institutional void' noemt - een institutionele leegte, hier duidend op het idee dat er (nog) geen algemeen geaccepteerde regels en normen zijn waartegen kwaliteit, legitimiteit en efficiency van CBI's kunnen worden beoordeeld, noch instrumenten waarmee toezicht en sturing op $\mathrm{CBI}$ 's in gereguleerde domeinen haalbaar is.

\footnotetext{
${ }^{1}$ Zie www.douwenkoren.nl/kopie-van-rapport-crowdfunding-nl-2.

${ }^{2}$ Zie www.maex.nl.

${ }^{3}$ Zie www.makerscene.io.

${ }^{4}$ Voorbeelden van Studio Wolfpack, Crowd-based Innovation, uit: Lab Results, 2017.
} 
In dit artikel beschrijven en problematiseren we $\mathrm{CBI}$ als fenomeen en presenteren we een typologie aan de hand waarvan we CBI-initiatieven kunnen indelen en duiden. We illustreren die typologie aan de hand van drie beknopte voorbeelden van hoe CBI's het institutionele landschap uitdagen en tonen de relevantie van een gecombineerd empirisch/normatief perspectief. Op basis hiervan presenteren we een onderzoeksagenda voor empirische en normatieve analyse van CBI's tegen een achtergrond van institutionele leegte.

\section{Crowd-based innovaties en institutionele leegte als empirisch en normatief vraagstuk}

Hoewel er een groeiende wetenschappelijk aandacht bestaat voor CBI-ontwikkelingen, ontbreekt een systematische studie naar de drijvende krachten hierachter, alsmede naar de mogelijke struikelblokken richting implementatie. Tot dusverre hebben bijdragen aan een discussie over deze onderwerpen zich toegespitst op technologie-gebaseerde platformen als een economisch verschijnsel (zoals de 'sharing economy; Frenken, 2016), of op sectorspecifieke ontwikkelingen zoals de rol van energie-coöperatieven in de energie transitie (bijv. Yildiz, 2014), gezondheids- en veiligheidsaspecten van off-grid watervoorzieningen (Sojka et al., 2016), en de waarde van (digitale) informatie in bevoorradingsketens (bijv. Zuidwijk \& Veenstra, 2015). Wat dat betreft, is het tijd om voorbij de hype te gaan en echt te kijken naar de mogelijke mismatch tussen dit soort nieuwe vormen van innovatie en de bestaande, geïnstitutionaliseerde wereld waarin we impliciet of expliciet allerlei belangrijke waarden en afwegingen hebben regels, normen, organisaties of rollen.

Technologie speelt een sleutelrol bij het mogelijk maken van CBI's. Zoals eerder is vermeld, kan de beschikbaarheid van kleinschalige en betaalbare technologieën (zoals zonnepanelen, 3D -printers, ICT, drones, etc.) faciliterend werken, maar het heeft ook een keerzijde. De meeste aspecten in onze samenleving zijn op enige wijze gereguleerd en niet zelden fors gereguleerd. Formele en informele wetten en regels, een bepaalde rol- en verantwoordelijkheidsverdeling, routines, marktmechanismen, toezicht en handhaving vormen samen een complex institutioneel stelsel. CBI's kunnen hierin op een aantal vlakken disruptief werken:

- De bestaande institutionele context waar CBI's aan raken, zijn geënt op een bekende en gevestigde set van partijen, met doorgaans heldere en vastomlijnde verantwoordelijkheden. Eventueel technische elementen en infrastructuren zijn daaraan gekoppeld. Bijvoorbeeld, op het gebied van energievoorziening wordt er in alles eigenlijk uitgegaan van een heldere scheiding tussen energieproducent, de leverancier, de netbeheerder en de consument. In CBI's nemen anderen een deel van die rollen over en combineren ze deels, maar niet noodzakelijk op de wijze waarop het huidige stelsel van regels en rollen is ingericht. Zeker wanneer CBI's voorzien in taken die voorheen werden uitgevoerd door (semi)publieke instanties of organisaties met een publieke nutsfunctie, ontstaan mogelijk 'gaten' in de verdeling van verantwoordelijkheden, aangezien juist de taken van dergelijke instanties vaak gepaard gaan met een specifieke publieke opdracht. Het bestaande stelsel van regels en rollen loopt dan achter op de innovatie en laat mogelijk bepaalde verantwoordelijkheden onbedeeld.;

- Soms zijn er regels die CBI's moeten aanmoedigen, bijvoorbeeld de zogenaamde experimenteerbepaling in de nieuwe Omgevingswet (artikel 23.2). Dergelijke regels creëren een speelveld met twee snelheden; de gevestigde partijen die voor stabiliteit moeten zorgen en aan talloze regels moeten voldoen, en nieuwkomers, die bijvoorbeeld meer ruimte krijgen en van wie niet wordt verwacht dat zij aan collectieve behoeften voldoen.

- Zeker bij gereguleerde domeinen zijn er meestal publieke belangen mee gemoeid en de institutionele structuren van zo'n domein ontlenen hun legitimiteit uiteindelijk aan democratische processen, transparantie en representatie. Bij CBI's hoeft dat niet het geval te 
zijn; aan de processen waarin die crowds zich organiseren, de innovatie vormgeven en implementeren, hoeft zeker geen democratische legitimiteit ten grondslag te liggen.

- In de combinatie van het bovenstaande (een innovatie die de ruimte krijgt, ontsnapt aan bestaande institutionele kaders dan wel die uitdaagt, en een gebrek aan democratische legitimiteit) bestaat het gevaar van een tweedeling waarbij de kosten van het collectieve of publieke belang komen te liggen bij diegenen die niet of minder in staat zijn om van de mogelijkheden van CBI's gebruik te maken. Om bij het voorbeeld van de energiesector te blijven: als een bepaalde groep in staat is en de ruimte krijgt om lokale energie gemeenschappen op te richten en voor eigen energievoorziening zorg te dragen, komen de kosten voor het behoud van de infrastructuur die de rest moet voorzien van energie, te liggen bij een kleinere groep die om een of andere reden niet in staat is om of deel wil nemen aan die communities.

De vraag naar sturing op en verantwoordelijkheden in CBI's vergt een interdisciplinaire (empirische en normatieve) aanpak, waarbij de faciliterende rol van technologie bestudeerd moet worden met het oog op de impact die zij heeft op bestaande gebruiken en instituten, en de manier waarop zij publieke waarden onderschrijft of bedreigt (vgl. Taebi et al., 2014). De bovenstaande disrupties van het bestaande speelveld moeten in kaart worden gebracht. Het bestuurskundeveld kan hierin een belangrijke rol spelen, juist in het door de hype heen prikken en echt empirisch te bestuderen welke partijen betrokken zijn, welke rollen en belangen zij hebben, hoe de innovatieprocessen eruitzien, wat de interactie met bestaande instituties en regelgeving is, en welke spanningen dat oplevert. En wat zijn eigenlijk de werkelijke effecten van CBI's? Daar is op dit moment erg weinig zicht op, wat problematisch is, aangezien er vrijwel altijd op enige wijze publieke waarden en belangen mee gemoeid zijn. Het doel van onderzoek op dit terrein zou moeten zijn om te begrijpen hoe governance van verantwoordelijkheden voor het waarborgen van publieke waarden (zoals legitimiteit, fairness, kwaliteit, efficiency) plaats kan vinden bij CBI's. Er zijn vanuit dit perspectief verschillende mogelijke beginpunten voor het begrijpen van CBI's in institutional voids; waaronder theorieën over network governance (Hendriks, 2008), sociale innovatie (Westley, 2013) en institutionele theorie (Smith, 2007).

Het bestuderen van CBI's kan echter niet los worden gezien van de normatieve kant. Het betrekken van individuen in het financieren of sturen van innovaties en het in staat stellen van ieder individu om een eigen mini-bedrijfje te starten, kan immers als iets inherents 'goeds' worden gezien. Het idee dat dit in goede banen en ten bate van publieke waarden geleid moet worden middels het aanpassen van bestaande of introduceren van nieuwe vormen van sturing, is al niet minder normatief. Wat te denken van een potentiële botsing tussen publieke waarden, met aan de ene kant het belang van zelforganisatie en participatie in innovaties en aan de andere kant het waarborgen van voorzieningen voor iedereen? En wat betekent een democratisch tekort van CBI's voor hun legitimiteit? Het is ook belangrijk om te weten welke verdeling van verantwoordelijkheden als 'eerlijk' kan worden beschouwd (Nihlén Fahlquist, 2006). Dit is des te belangrijker wanneer een herverdeling van verantwoordelijkheden ook de borging van publieke waarden raakt (Doorn, 2016; Thaler \& Hartmann, 2016). Relevante ethische raamwerken lijken die van individuele- en staatsverantwoordelijkheden in verschillende gebieden, zoals klimaatverandering (Jamieson, 2010; Butler \& Pidgeon, 2011), burgerschap (Vanderheiden, 2016) en impactevaluatie (Van Wee \& Roeser, 2013; Geurs, Patuelli \& Ponce Dentinho, 2016).

We willen hier betogen dat een bestuurskundig perspectief op deze innovaties aangevuld, zelfs geïntegreerd, zou moeten worden met analyse van de normatieve aspecten van CBI's, specifiek in relatie tot publieke waarden. Onderzoek dat CBI's beschouwt als niet louter een economisch fenomeen, maar ook de sociale en ethische aspecten meeweegt, kan inzicht bieden in het veranderende landschap van verantwoordelijkheden van overheden en burgers (zie bijv. Loorbach en\& Rotmans, 2010; Nye, Tapsell 
\& Twigger-Ross, 2011). Om dit alles te begrijpen moeten we ook gevoelig zijn voor de rol van de technologie zelf en is ethische en empirische analyse nodig om de definitie, verdeling en toekenning van verantwoordelijkheden helder te krijgen. Andersom speelt het overigens ook; er is soms veel discussie over de ethische aspecten van een innovatie (bijvoorbeeld rondom Uber), zonder dat er recht wordt gedaan aan de complexiteit en diversiteit van het fenomeen. Aan deze tweevoudige focus kan het begrip van institutionele leegte bijdragen als een vernieuwende blik die zowel de potentie van CBI's als de mogelijke barrières ertegen kan duiden. Naast de academische relevantie kunnen antwoorden op dit vraagstuk worden gebruikt bij het veiligstellen van geaccepteerde publieke waarden, en daardoor bijdragen aan het verantwoord implementeren van CBI, zonder de positieve potentie te verliezen.

\section{Een typologie van crowd-based innovaties in institutional voids}

De beschreven empirische en ethische vragen zijn van belang om te begrijpen op welke wijze CBI's tot institutionele leegte leiden, wanneer en onder welke omstandigheden verantwoordelijkheden in en door CBI's verschuiven, en hoe deze bestuurd en verantwoord kunnen worden. Door de grote diversiteit aan dergelijke innovaties is een eerste, belangrijke stap daarin het kunnen onderscheiden van verschillende typen CBI. In dit artikel doen we een eerste aanzet tot een typologie van CBI's en illustreren deze aan de hand van een aantal voorbeelden.

We duiden CBI's aan de hand van twee dimensies. De eerste dimensie verwijst naar het niveau van connectiviteit tussen burgers die betrokken zijn bij een CBI (zie figuur 1). Een 'gemeenschap' verwijst naar een groep hecht verbonden burgers, die een sterke gemeenschapszin ervaren en wederzijdse relaties kennen. Gemeenschappen worden doorgaans gekarakteriseerd door een gedeeld doel of belang. Deze gemeenschap kan verbonden zijn via digitale middelen, maar uiteraard ook via directere communicatie. De andere kant van deze dimensie wordt ingenomen door de 'zwerm', wat verwijst naar een aggregaat van unilaterale interacties tussen twee individuen, niet zelden gemedieerd door een digitaal platform. Mensen in zwermen delen een belang, maar, in tegenstelling tot de 'gemeenschap', is dit vaak geen collectief belang. De tweede dimensie behelst de structuur van het netwerk. 'Peer to peer' doelt op een netwerk waarin geen sturende centrale actor bestaat, en interacties en relaties (variërend in zowel hechtheid als frequentie) relatief direct plaatsvinden tussen de mensen in het netwerk. 'Peer to principal' daarentegen duidt op een type netwerk waarbij er wél een centrale, sturende actor bestaat, die de input van deelnemers uit de gemeenschap of zwerm verzamelt en op basis daarvan een besluit neemt of op een andere manier handelt. 


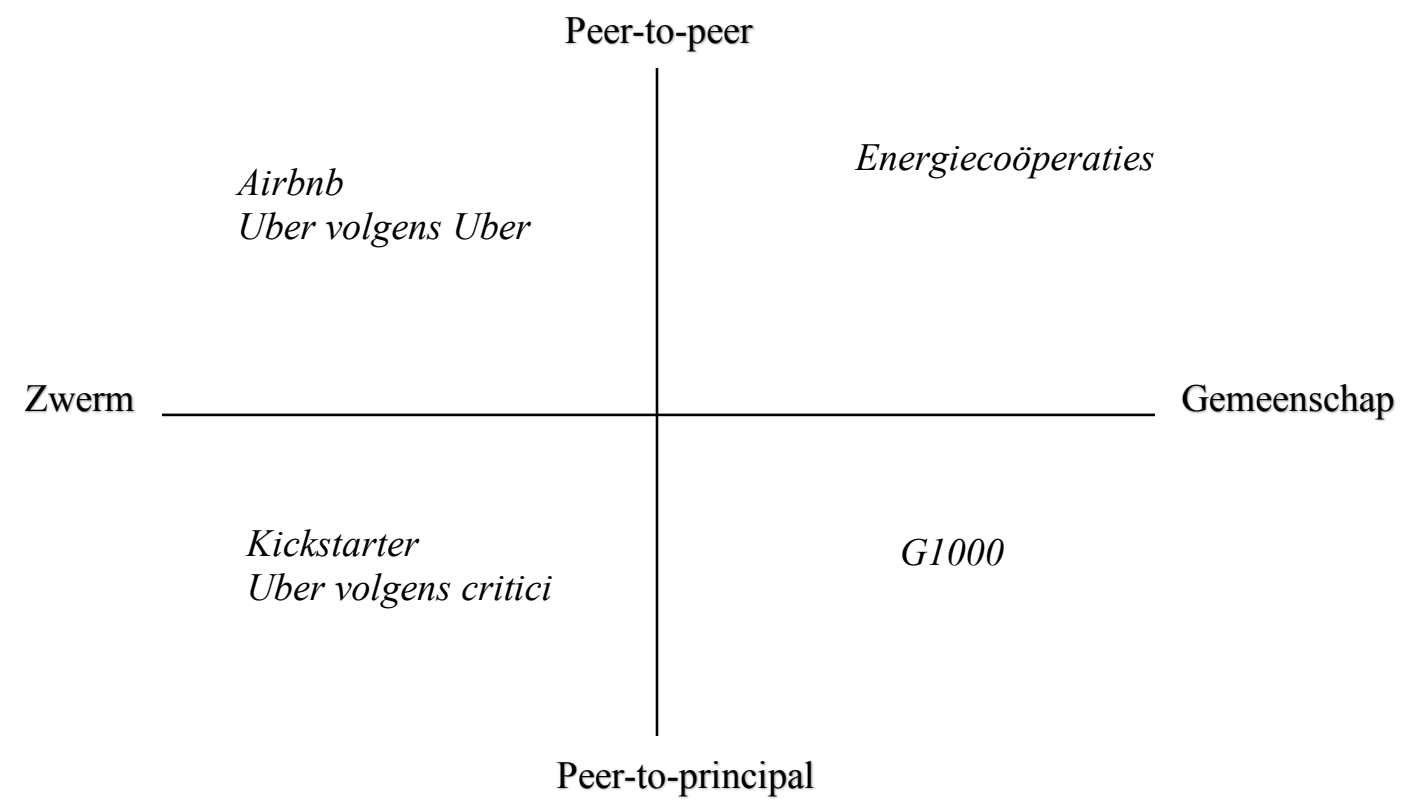

\section{Figuur 1 Typologie van CBI's}

We geven een drietal voorbeelden van CBI's die in de bovenstaande typologie geplaatst kunnen worden. Op dit moment hebben we deze initiatieven nog niet vanuit de hier voorgestelde invalshoek onderzocht, we bieden ze ter illustratie van hoe hun functioneren uitdagingen voor de status quo vormt.

Voor je Buurt is een crowdfunding-platform met projecten op lokaal niveau, ook 'civic crowdfunding' genoemd. Initiatiefnemers kunnen een voorstel plaatsen, en hierbij aangeven wat het streefbedrag is dat opgehaald moet worden (Voor je Buurt, 2017). De regels werken zo dat wanneer dit bedraag niet gehaald wordt, het project als geheel niet doorgaat en mensen die geïnvesteerd hebben hun geld terugkrijgen. Ongeveer vijftig procent van de aangemelde projecten wordt succesvol gefinancierd, en in deze gevallen ontvangt Voor je Buurt vijf procent van het opgebrachte bedrag (Eimers, 2016). Anders dan het meer internationaal georiënteerde Kickstarter — dat bij uitstek in het kwadrant linksonder van 'peer-to-peer' en zwerm ligt - wordt er bij veel projecten geappelleerd aan een gevoel van gemeenschap. Hoewel dit niet noodzakelijk aanwezig hoeft te zijn om te investeren in deze sociale projecten, bestaan er hoofdzakelijk ideeën die een buurt leefbaarder willen maken door bijvoorbeeld het aanleggen van een sociale ontmoetingsplek, het aanleggen van een buurttuin, of een bepaalde groep mensen iets extra's bieden door het organiseren van een dagje uit. Ook een verschil met Kickstarter is dat er hier begeleiding wordt aangeboden aan de initiatiefnemers, waardoor Voor je Buurt meer op de voorgrond treedt en het strikt genomen niet een peer-to-peer CBI is. Dit voorbeeld laat zien dat de typologie wel een goed startpunt is, maar dat CBI's complexe organisaties kunnen zijn met veelzijdige activiteiten die zich niet eenduidig laten classificeren. Sommige kritiekpunten op andere crowdfunding -initiatieven blijft echter overeind. Allereerst vindt er een selectie plaats van mensen die hieraan kunnen (en willen) deelnemen. Een financiële investering is niet aan iedereen besteed, en introduceert het gevaar dat vooral de belangen van degene met financiële slagkracht gediend zullen worden. Een gebrek aan regulatie van dit soort financiering is een tweede punt van zorg. Participanten zijn vaak niet doorgewinterde investeerders, en dus niet altijd goed toegerust om een weloverwogen beslissing te nemen. Problemen met transparantie van zowel het proces als het doel liggen op de loer. Een gebrek aan transparantie en toezicht kan ervoor zorgen dat er bij crowdfunding afwegingen gemaakt worden in het balanceren tussen kwaliteit en betaalbaarheid die onwenselijk blijken (Hossain \& Oparaocha, 2017). In het geval van Voor je Buurt worden deze zorgen onderkend, en tracht de organisatie aan deze zorgen tegemoet te komen door middel 
van informatieverstrekking en verbanden met (lokale) overheden. Hoewel er dus pogingen worden ondernomen om de potentiële gevaren in te dammen, is er nog onvoldoende onderzoek gedaan om hier een oordeel over te vellen.

Energievernieuwing zoals in Duitsland plaatsvindt met de 'Energiewende', heeft een grote impact op de gehele energiesector. Na enkele jaren blijkt (mede) dankzij de energiecollectieven in de Duitse Energiewende de helft van de duurzame energieproductie in handen van burgers, en zijn er grote stappen gemaakt richting klimaat-neutrale manieren van het opwekken van energie. Het wordt breed gezien als een zeer geslaagd voorbeeld van participatie van burgers bij een ingrijpend project (Quitzow et al., 2016). Zo beschouwd valt dit zeer te prijzen, en is de vernieuwing vooral een positief teken. Echter, de bijdrage die een Duits huishouden hieraan betaalt, is sinds 2000 gestegen van 43 naar 1240 euro per jaar. De facto is dit een geldstroom van de stad naar het platteland en van mensen met weinig investeringsmogelijkheden naar mensen met meer. Ook in Nederland wordt hiervoor gewaarschuwd, onder andere door CE Delft (Studio Wolfpack, 2017). Hierbij komt nog dat er (te) weinig nieuwe governance structuren zijn geïntroduceerd om met eenzelfde mate van stabiliteit en helderheid te regelen wie er verantwoordelijk is voor onderhoud en vernieuwing van de infrastructuur. Ook is er tijdens deze verschuiving meer aandacht nodig voor het betrekken van de nieuwe opwekkers bij het aanpakken van deze vraagstukken (Schweizer et al., 2016).

Deelfietsbedrijven willen graag het vervoer in grote steden efficiënter maken, door op strategisch gekozen plekken fietsen aan te bieden die tegen betaling tijdelijk gebruikt kunnen worden. Het idee achter dit soort initiatieven is dat er op deze manier in totaal minder fietsen nodig zullen zijn. Echter, de openbare ruimte in de grote steden wordt steeds voller. Het is in het teken van duurzaamheid en klimaatvriendelijkheid te prijzen dat meer organisaties kijken naar efficiënte manieren om vervoer te organiseren. Mensen met een migrantenachtergrond, een groeiende demografische groep, maken hier beduidend minder gebruik van. Gecombineerd met het feit dat veel van deze 'deelfietsen' ongebruikt blijven maar wel ruimte innemen, zien we dat deze initiatieven de openbare ruimte verstoren zonder dat er eerst gedegen onderzoek is gedaan naar de mate van investering die efficiënt zou zijn. Ten tweede bestaan er groepen die geen tot weinig behoefte hebben hieraan. Buiten dat veel leden van de lokale bevolking zelf al een fiets hebben, en wellicht niet staan te springen om deze in te ruilen voor een gedeeld exemplaar, bestaat er ook een grote groep die sowieso niet enthousiast is over fietsen en wel hinder ondervindt van het aanbod.

\section{Bij wijze van conclusie: een multidisciplinaire onderzoeksagenda voor crowd-based innovaties in een geïnstitutionaliseerde context}

Bovenstaande voorbeelden geven de spanningen beknopt weer, maar zijn wel illustratief voor de mogelijke impact van CBI's. Het sterkt ons in het betoog dat onderzoek naar de gevolgen van de verschuiving van verantwoordelijkheden expliciet de empirische vraagstukken zal moeten verrijken met aandacht voor normatieve kwesties, ook om vragen te stellen die voorheen niet relevant waren (of leken). Als onderdeel van het onderzoeksproject 'Crowd-based innovations: Governing transition of responsibilities' gaan wij deze vragen de komende jaren onderzoeken voor aantal CBI's in drie domeinen: energie, water en logistiek. Op basis van de constateringen die we in dit artikel uiteen hebben gezet, willen we - bij wijze van conclusie - een brede, multidisciplinaire onderzoeksagenda uiteenzetten.

Een eerste vraagstuk dat wij willen adresseren, gaat over hoe vanuit een empirisch perspectief definities en verdelingen van verantwoordelijkheden bij crowd-based innovaties ontstaan, en hoe governance geregeld is en kan worden. Hierop volgt de praktische vraag hoe crowd-based innovaties de bestaande 
structuren uitdagen. Er kan niet louter worden gekeken naar de kansen die dit type innovaties wil benutten. Het vervangen van bestaande, democratisch legitieme instituten of het vervagen van de grenzen van bevoegdheden van deze instituten gaat gepaard met het verlies van de functie die deze instituten hebben. Daar zijn impliciet of expliciet belangrijke waarden ondergebracht, en een transitie zal dus rekening moeten houden met het opvangen hiervan. Een blik op het economische voordeel van nieuwe manieren van organiseren moet ook gevoelig blijven voor wat er verloren gaat. Daarbij komt nog dat juist het type disruptieve innovatie dat CBI's najagen zich bevindt op onbekend terrein, en dat intenties niet altijd vertaald worden naar succes in de praktijk. Innovaties op hun beloop laten en de gevolgen achteraf beoordelen is niet altijd de juiste optie. Hierbij moet niet vergeten worden dat initiatieven in de deeleconomie (deels) competitief (en daarmee aantrekkelijk) zijn door te besparen op de kosten die geassocieerd worden met regulering (Gonzalez-Padron, 2017). Het behalen van voordeel op dit vlak vereist dus het vermijden of wijzigen van regels die wel voor anderen gelden. Dat is niet per se enkel een uitdaging voor de regelgeving zelf, maar - zo betogen Biber et al. (2017) - het kiezen voor het weglaten van regulering op de deeleconomie is een verkapte vorm van subsidiëring, hetgeen tot ongelijke kansen op de markt leidt. Het opzoeken van de 'institutional void' kan in eerste instantie lonen, maar dan vooral voor de innovators en met een onbekend langetermijneffect. Dit levert belangrijke vragen op rondom de feitelijke en wenselijke toebedeling van verantwoordelijkheden, de trade-offs tussen verschillende waarden, en de rol van sturing en toezicht op CBI's, zowel empirisch als normatief bezien. De groei van CBI's past ook in het beeld van een terugtredende overheid die inzet op een participatiesamenleving. De overdracht van verantwoordelijkheden is echter geen proces dat zonder reflectie en begeleiding kan plaatsvinden. Hoe staat het bijvoorbeeld met (openbaar) bestuur en het waarborgen van publieke waarden? Wie kan er ingrijpen in het geval dat er onwenselijke effecten voelbaar worden? Deze vragen verdienen aandacht nu de crowd een toverwoord lijkt, zeker als er aantoonbare economische voordelen te behalen zijn en een aantal initiatieven direct de grijze gebieden van regelgeving opzoeken. Hoewel de mogelijkheden tot het gebruiken van middelen (zoals tijd, geld, creativiteit, etc.) die in een gemeenschap bestaan een positieve trend kunnen zijn, moet dit niet leiden tot een noodzaak, bijvoorbeeld door actief verantwoordelijkheden aan die gemeenschappen toe te schrijven. Dan spelen vraagstukken rondom democratische legitimiteit, transparantie en representativiteit des te meer. Hier komt de verander(en)de rol van burgers weer naar voren; is deze bijvoorbeeld wel toegerust om de juiste afwegingen te maken? In het geval van crowdfunding zoals bij Voor je Buurt wordt er bijvoorbeeld expert-kennis vereist die niet per se aanwezig is. Inzicht in de belangen en processen klinkt haast triviaal, maar is een noodzakelijk startpunt om die grote vragen te kunnen beantwoorden.

Een tweede punt wordt gevormd door een meer normatief vraagstuk: wie worden geraakt door de veranderende verantwoordelijkheden die voortvloeien uit CBI's? En welke publieke waarden — zoals legitimiteit, fairness, kwaliteit en efficiency — spelen hier mee? Een mogelijk startpunt in deze normatieve kwestie is in eerste instantie ook empirisch; over wie hebben we het als we spreken over de crowd? Dit is hoogst context-afhankelijk, elke innovatie staat immers in verbinding met een andere groep mensen. Hierbij moet de crowd niet alleen worden gezien als een bepaalde hoeveelheid mensen. Belangrijker is de identiteit van deze groep, de (relatieve) autonomie, en de samenstelling. Doordat er al dan niet bewust keuzes worden gemaakt met betrekking tot deze punten, kan een project dat inzet op laagdrempeligheid ongemerkt toch keuzes maken die tot uitsluiting leiden. Niet iedereen kan participeren in elke CBI, omdat de context waarin deze opereert inherent barrières op kan werpen. Bij informatievergaring over specifiek gebruik van een dienst of product, of over een bepaalde demografie is dit vanzelfsprekend, maar uitsluiting kan ook plaatsvinden door een bepaald model van sturing of samenwerking te kiezen of het gebruik te vereisen van een bepaalde technologie die niet voor iedereen toegankelijk is. Er is een risico dat de crowd bestaat uit een elite, waardoor CBI een mechanisme wordt 
waarlangs ongelijkheid binnen de samenleving wordt vergroot. De keuzes over wie er tot de doelgroep behoort en hoe deze wordt benaderd zijn derhalve niet neutraal, en hebben consequenties voor zowel het functioneren van de CBI in kwestie als de conceptualisatie ervan, met bijbehorende toepasselijke regelgeving. Zeker in het geval dat CBI's publieke taken (pogen) over te nemen moet er kritisch gekeken worden naar hoe de waarborging van functies en waarden geregeld is. Een gerelateerd punt gaat over het feit dat er een reëel gevaar is dat er een onevenredig beroep wordt gedaan op individuen en groepen, ook omdat er door succesvolle voorbeelden een verwachtingspatroon kan ontstaan dat niet aansluit bij de mogelijkheden. Meer algemeen speelt de vraag naar de wenselijkheid van dit alles; het zijn niet louter kansen, er gaat ook wat verloren. Continuïteit, stabiliteit, inclusiviteit et cetera zijn kernwaarden die niet gegarandeerd zijn bij dit soort ontwikkelingen. Wie grijpt in wanneer er schadelijke effecten te merken zijn?

De twee pijlers van een empirische en normatieve analyse van CBI's moeten geïntegreerd worden om te komen tot de formulering van een legitieme governance configuratie. Een multidisciplinair onderzoek met als theoretische lens de institutional void kan wat ons betreft als startpunt dienen om inzichten te verwerven om CBI's niet in de kiem te smoren, terwijl er expliciet aandacht blijft voor de waardevolle elementen van de structuren die hierdoor uitgedaagd worden.

\section{Literatuur}

Biber, Eric and Light, Sarah E. and Ruhl, J. B. and Salzman, James E. (2017). Regulating Business Innovation as Policy Disruption: From the Model T to Airbnb. Vanderbilt Law Review, Forthcoming; Vanderbilt Law Research Paper No. 17-24; UCLA School of Law, Public Law Research Paper No. 17-18. Available at SSRN: https://ssrn.com/abstract=2951919.

Butler, C., \& Pidgeon, N. (2011). From 'flood defence' to 'flood risk management': Exploring governance, responsibility, and blame. Environment and Planning C-Government and Policy, 29(3), 533-547. doi:10.1068/c09181j

Charbit, C. and G. Desmoulins (2017). Civic Crowdfunding: A collective option for local public goods?. OECD Regional Development Working Papers, 2017/02, OECD Publishing, Paris.

Doorn, N. (2016). Distributing responsibilities for safety from flooding. FLOODrisk 2016 - 3rd European Conference on Flood Risk Management, Lyon.

Eimers, D. (2016). Goodwill genereert geld. Jeugd en Co, 10(5), 10-14.

Frenken, K. (2016). Sharing economy under one denominator? (In Dutch: Deeleconomie onder één noemer?). Inaugural address. Utrecht University.

Geurs, K. T., Patuelli, R., \& Dentinho, T. P. (Eds.). (2016). Accessibility, Equity and Efficiency: Challenges for Transport and Public Services. Edward Elgar Publishing. Northampton, USA.

Gonzalez-Padron, T.L. (2017). Ethics in the sharing economy: Creating a legitimate marketing channel. Journal of Marketing Channels, 24(1-2), 84-96.

Hajer, M. (2003). Policy without polity? Policy analysis and the institutional void. Policy Sciences, 36(2), 175-195.

Hendriks, C.M. (2008). On inclusion and network governance: The democratic disconnect of Dutch energy transitions. Public Administration, 86(4), 1009-1031. doi:10.1111/j.14679299.2008.00738.x

Hossain, M., \& Oparaocha, G.O. (2017). Crowdfunding: motives, definitions, typology and ethical challenges. Entrepreneurship Research Journal, 7(2).

Jamieson, D. (2010). Climate change, responsibility, and justice. Science and Engineering Ethics, 16(3), 431-445.

Loorbach, D., \& Rotmans, J. (2010). The practice of transition management: Examples and lessons from four distinct cases. Futures, 42(3), 237-246. 
Nihlén Fahlquist, J. (2006). Responsibility ascriptions and Vision Zero. Accident Analysis \& Prevention, 38(6), 1113-1118, doi:10.1016/j.aap.2006.04.020

Nye, M., Tapsell, S., \& Twigger-Ross, C. (2011). New social directions in UK flood risk management: Moving towards flood risk citizenship? Journal of Flood Risk Management, 4(4), 288-297.

Quitzow, L., Canzler, W., Grundmann, P., Leibenath, M., Moss, T., \& Rave, T. (2016). The German Energiewende - What's happening? Introducing the special issue. Utilities Policy. Volume 41, August 2016, Pages 163-171.

Schweizer, P.J., Renn, O., Köck, W., Bovet, J., Benighaus, C., Scheel, O., \& Schröter, R. (2016). Public participation for infrastructure planning in the context of the German 'Energiewende'. Utilities Policy, 43, 206-209.

Smith, C.R. (2007). Institutional determinants of collaboration: An empirical study of county openspace protection. Journal of Public Administration Research and Theory, 19(1), 1-21, doi:10.1093/jopart/mum037

Sojka, S., Younos, T., \& Crawford, D. (2016). Modern urban rainwater harvesting systems: Design, case studies, and impacts. In T. Younos \& T.E. Parece (Eds.), Sustainable water management in urban environments (pp. 209-234). Springer.

Studio Wolfpack (2017). Crowd-based innovation. In Lab Results.

Taebi, B., Correljé, A., Cuppen, E, Dignum M. \& Pesch, U. (2014). Responsible innovation as an endorsement of public values: the need for interdisciplinary research. Journal of Responsible Innovation, 1:1, 118-124, DOI: 10.1080/23299460.2014.882072.

Thaler, T., \& Hartmann, T. (2016). Justice and flood risk management: Reflecting on different approaches to distribute and allocate flood risk management in Europe. Natural Hazards, 83(1), 129-147, doi: 10.1007/s11069-016-2305-1

Vanderheiden, S. (2016). The obligation to know: Information and the burdens of citizenship. Ethical Theory and Moral Practice, 19(2), 297-311, doi: 10.1007/s10677-015-9618-0

Voor je Buurt. (2017). https://www.voorjebuurt.nl/civic-crowdfunding/. Laatst geraadpleegd op 2 september 2017.

Wee., B. van, \& Roeser, S. (2013). Ethical theories and the cost-benefit analysis-based ex ante evaluation of transport policies and plans. Transport Reviews, 33(6), 743-760.

Westley, F. (2013) Key Note Lecture The History of Social Innovation, at NESTA Conference Social Frontiers: The Next Edge of Social Science Research, 14-15 November 2013, London UK. http://www.nesta.org.uk/sites/default/files/key_note_speech_frances_westley_on_the_history_ o social_innovation.pdf

Yildiz, Ö. (2014). Financing renewable energy infrastructures via financial citizen participation - The case of Germany, Renewable Energy, 68, 677-685, doi: 10.1016/j.renene.2014.02.038

Zuidwijk, R.A., \& Veenstra, A.W. (2015). The value of information in container transport. Transportation Science, 49(3), 675-685. doi:10.1287/trsc.2014.0518

Informatie over de auteurs:

M.J. Slot, MSc is promovendus op het project 'Crowd-based innovation: Governing transition of responsibilities' bij de sectie Ethics and Philosophy of Engineering, faculteit Techniek, Bestuur en Management van de TU Delft.

Dr. ir. E.H.W.J. Cuppen is universitair hoofddocent Governance of Sustainability \& Public Engagement bij de sectie Policy, Organisation, Law \& Gaming, faculteit Techniek, Bestuur en Management van de TU Delft. 
Prof. dr. mr. ir. N. Doorn is hoogleraar Ethics of water engineering bij de sectie Ethics and Philosophy of Engineering, faculteit Techniek, Bestuur en Management van de TU Delft.

M.J. Galeano Galvan, MSc is promovenda op het project 'Crowd-based innovation: Governing transition of responsibilities' bij de sectie Policy, Organisation, Law \& Gaming, faculteit Techniek, Bestuur en Management van de TU Delft.

Dr. ing. A.J. Klievink is universitair hoofddocent Collaborative Digital Governance en sectieleider bij de sectie Policy, Organisation, Law \& Gaming, faculteit Techniek, Bestuur en Management van de TU Delft. 